\title{
Article
}

\section{An exploratory investigation of organic solid waste for energy use in the Dominican Republic: Case of the Municipality of Puñal, Santiago.}

\author{
Edian F. Franco ${ }^{1,2, \ddagger}$, W Wilfredo Padrón ${ }^{3, \ddagger}$ (1) and Karina Pérez Teruel ${ }^{3, \text { (1) }}$ \\ 1 Instituto de Innovación en Biotecnología e Industria (IIBI), Santo Domingo, República Dominicana; \\ edianfranco@ufpa.br \\ 2 Instituto Tecnologico de Santo Domingo (INTEC), Santo Domingo, República Dominicana \\ 3 Universidad Abierta para Adultos (UAPA), Santiago, República Dominicana; karinaperez@uapa.edu.do; \\ wilfredopadron@f.uapa.edu.do \\ * Correspondence: karinaperez@uapa.edu.do; (K.P.T) \\ $\ddagger$ These authors contributed equally to this work.
}

\begin{abstract}
One of the biggest problems that the Dominican Republic has had in recent decades is the efficient management of solid waste produced by the population. This problem has worsened in recent years due to the decrease in available areas for the construction of sanitary landfills, the lack of recycling culture in the population, the deficiency in waste collection, and the scarce legal controls aimed at preserving water and air and soil, among other factors. The objective of this study was to explore the management of solid waste by the population and the municipality of Punal, province of Santiago, to evaluate and analyze the situation and generation of solid waste, municipal solid waste management services, and the attitudes of the population regarding recycling projects and waste management, to evaluate the viability and sustainability of the use organic waste for energy generation. A total of 275 households from 29 localities in the municipality of Puñal were surveyed, which allowed for a significant population sample. According to the results obtained, the most significant type of waste produced by families is organic waste, followed by plastic waste and paper. Of the total organic waste produced in the municipality, $53 \%$ of solid waste is disregarded through the municipal waste collection system, while $47 \%$ is used as plant fertilizers or animal feed. On the other hand, most households receive the municipal waste collection service and pay for this service. The results of our research show that the implementation of an energy production system based on organic waste would be viable in the municipality of Puñal. However, a more efficient waste collection system would be necessary and the development of programs and projects that allow all households to participate in the system.
\end{abstract}

Keywords: Household solid waste; Dominican Republic; separation at source; Organic solid waste, Household survey; Cibao; North region.)

\section{Introduction}

The generation of solid waste in the Dominican Republic is considered a significant problem due to the decrease in available areas for the construction of sanitary landfills, the lack of recycling culture in the population, and the few legal controls aimed at preserving water, air, and soil, among other factors $[1,2]$

In recent years, the country has undertaken a process of ordering and regulating solid waste through mechanisms such as the Policy for the Integral Management of Municipal Solid Waste (MSW), issued by the Ministry of the Environment in 2014. This strategy establishes that the solution to the problem of solid waste in the Dominican Republic must be based on a global and long-term vision, which can respond to the needs and circumstances of the different municipalities and provinces of the country, seeking 
an adequate comprehensive solution from the economic, social and environmental point of view, with the active and conscious of citizens [1].

At the same time, the General Law of Integral Management and Co-processing of Solid Waste, No. 225-20, established the legal regime of integrated waste management to promote reduction, reuse, recycling, use, and recovery. These legal instruments show the need for the country to take advantage of its waste to generate new products and use its energy potential, among other possibilities offered by the adequate treatment of waste [3].

Despite these regulations, the efficient management of municipal solid waste represents one of the main challenges for most municipal managers due to the deficiencies accumulated over the years. These challenges include the deficiency in the collection of domestic and industrial waste, the inefficiency of the collection routes, the final disposal of waste that is traditionally taking place in the open air without meeting minimum sanitary and environmental standards, in addition to the lack of public policies and municipal projects for waste recycling and revaluation [2].

This situation has caused significant environmental and social impacts. It can be mentioned the degradation of the areas near the final waste disposal sites, due to the production of gases and unpleasant odors, the production of leachates that can contaminate the water sources and the surrounding land. These situations generate significant public health risks due to air, soil, and water [1]. Also, as demonstrated by a study conducted by the municipality of Jarabacoa demonstrated, open dumps cause the proliferation of insects, such as mosquitoes which are responsible for the transmission of Dengue, Zika, and Chikungunya viruses (Aedes aegypti and Aedes albopictus), as well as West Nile virus and lymphatic filariae. This research recommends strengthening municipal measures to reduce the health risks generated by insects in the country [4].

In general terms, the problem described above is particularly relevant when considering that population growth and economic development in recent decades have led to an exponential increase in waste in different country areas. This increase has further complicated the steps and mechanisms that must be established to implement an efficient process between waste generation, its collection, and final disposal [5]. The complexity of this first stage of the treatment process of solid waste generated by Dominican households has been highlighted in the National Multipurpose Household Survey [6]. According to their data, $85.2 \%$ of households dispose of their solid waste through the collection mechanisms of the municipalities, $7.5 \%$ burn it, and 3.5\% throw them in the yard, lot, or nearby streets. These last two incorrect forms of disposal are used by $11.0 \%$ of Dominican households [6]. Regarding the waste compositions produced, $60 \%$ is organic matter; $10 \%$ cardboard; $6 \%$ paper, plastic, and glass; $4 \%$ of metals. Other unidentified materials represent $8 \%[1,2]$.

In addition to the damage to the environment, as mentioned before, and the exponential health risk that those practices cause, the incorrect handling of solid waste limits the possibilities offered by some of the generated waste, especially the organic waste, which could be used in the process of energy generation through the biogas producing biodigesters, by anaerobic digestion of organic matter. Furthermore, this process yields other by-products such as biol and biosol. The former is a valuable complex psychostimulant fertilizer, rich in essential nutrients for plants growth and development, and its application to crops substantially improves their quality and production [7-9]. Biosol is a biodigester output effluent that, when used in plantations, significantly influences the growth and development of crops [7,8,10].

In this research, the province and municipality selected were due to inconsistent solid waste generation, collection, and energy use behavior compared to the national level. According to figures offered by the Dominican Municipal League, in 2019, the country produced approximately 16,000 tons of waste per day [11]. The North region (Cibao) produced approximately 3,713 tons per day, making it one of the central wasteproducing regions, ranking only after Greater Santo Domingo [12]. 
In the so-called Cibao North, which in addition to the province of Santiago, Puerto Plata, and Espaillat, $90.4 \%$ of households dispose of their solid waste through the municipal collection, $6.0 \%$ burn and $1.2 \%$ throw it away in the yard, in the lot or the street. These last two incorrect forms of disposal are used by $7.2 \%$ of the households in the region [6]. However, these regional and provincial figures do not show similar indicators in Puñal. According to the data provided by the National Statistics Office, during 2020 [13], solid waste disposal in the municipal territory behaved as follows:

- $75.5 \%$ of households dispose of their solid waste through municipal collection.

- $\quad 0.1 \%$ of households dispose of their solid waste through collection by a private company.

- $\quad 24.2 \%$ of households dispose of their solid waste by burning or dumping in backyards, lots, or nearby streets [13].

As can be seen, almost a quarter of the households in the municipality of Puñal incinerate or dump their waste in open spaces, often near or over water sources. This situation causes potential effects on the environment and is a complicated scenario from an epidemiological point of view and waste from an energy point of view. This situation motivated this investigation to identify the causes that influence the manifested bad practices in the Puñal municipality, Santiago province, regarding the generation and collection of solid waste, especially organic waste.

This study aims to explore solid waste management by the population and the municipality of Puñal, Santiago province, Dominican Republic, to evaluate and analyze the generation, management, and disposal of solid waste, as well as the population's attitudes towards solid waste recycling and reuse projects of solid waste, to assess the feasibility and sustainability of using organic waste for power generation.

\section{Materials and Methods}

\subsection{Description of the Study Area}

The Puñal municipality is located in the province of Santiago, in the Cibao Norte region of the Dominican Republic (Figure1). In addition to its municipal seat, it is made up of the Municipal Districts of Guayabal and Canabacoa. It has an area of $60.8 \mathrm{~km} 2$, and in 2010 was inhabited by a total of 23,856 inhabitants, with a population density of 765 inhabitants $/ \mathrm{km}^{2}$. For that same year, living conditions reflected that $98.9 \%$ of households had electricity and 25.7 had a car. Regarding construction, $1.1 \%$ of the houses had roofs made of asbestos, cement, yagua, cane, or other materials. $0.7 \%$ had palm, yagua, and tejemanil board walls, while $1.8 \%$ had floors of earth or similar materials [13]. 


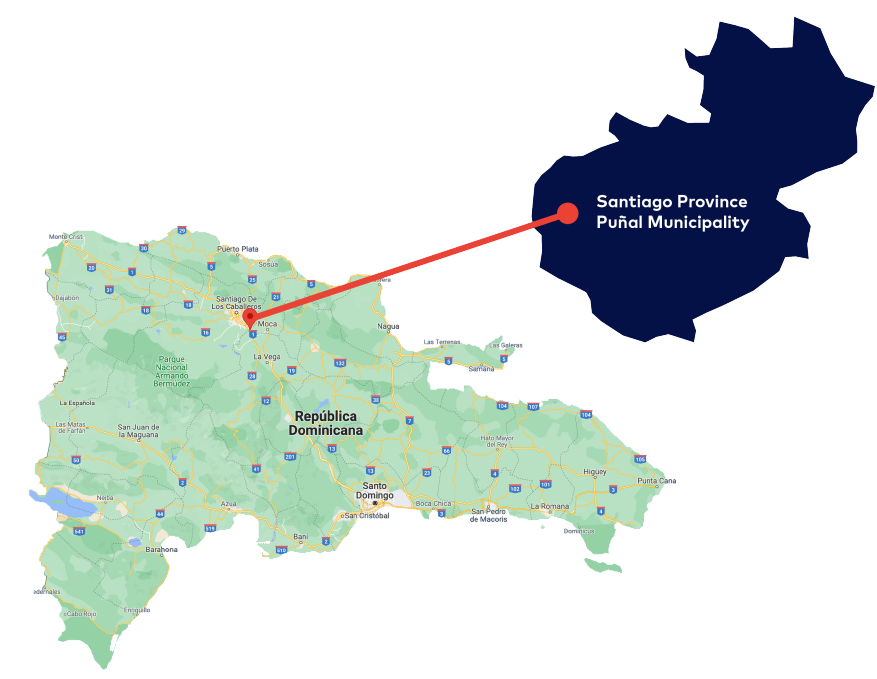

Figure 1. Provincial map and of the communities that were interviewed during the study.

$\mathrm{s}$ for environmental data, which includes the final disposal of garbage, it indicates that $80.4 \%$ of households have access to the public water supply network. Of these, $6.0 \%$ use solid fuels for cooking, while $25.7 \%$ do not have a toilet in their living spaces [13]. From an economic point of view, Puñal is a rural community with an agricultural vocation, where livestock, fishing, and forestry activities stand out. It also has commercial and industrial establishments, among others. In 2018 it did not have hotels, country plots, or mining operations, and it had 276 grocery stores [13].

\subsection{Design of the investigation}

For the research development, it was decided to design and apply a survey with a qualitative methodological approach since it was supported by the collection of data on the variables previously selected. Through a descriptive and non-experimental study, the researchers seek to identify, classify, and categorize the variables and indicators manifested in the phenomenon under investigation without altering it. The study includes socioeconomic variables, perception of municipal services, generation processes, management, and disposal of solid waste.

The general method applied was inductive with simple probability sampling, based on collecting data from a random sample and representative of the total population. The selected technique was the survey, applying a closed and complete questionnaire of the phenomenon studied. The authors designed a 24-questions questionnaire (Supplementary file 1), which made it possible to identify the main variables related to solid waste management in the selected communities of the municipality.

The survey was divided into six sections:

1. Socioeconomic: Neighborhood/community, Education level, Member of the family, and Family Income Level.

2. Waste generation: Likert frequency scale (1 - Never, 2 - Rarely, 3 - Sometimes, 4 Often, 5 - Always) on the generation of organic waste (food), Paper and Cardboard, Plastics, Metals, Glasses, Electronic waste, and other types of waste.

3. Storage, use, and disposal of waste: how the solid waste is stored at home, organic waste use, and solid waste disposal.

4. Municipal services: frequency of collection, payment of services, the final destination of waste.

5. Recycling: Separation of waste, participation in recycling programs, domestic waste recycling. 
6. Perception of waste management: evaluation of the perception of waste management in the municipality.

\subsection{Selection of samples}

The sample was selected based on the 2011 Puñal Municipal Sociodemographic Profile [14]. According to the data, the municipality of Puñal has 46,516 inhabitants, with 10,415 dwellings. The calculation of the sample has been made with the following equation:

The calculation of the sample was carried out with the following equation:

$$
S S=\frac{\frac{z^{2} * p(1-p)}{e^{2}}}{1+\left(\frac{z^{2} * p(1-p)}{e^{2} N}\right)}
$$

where, SS sample size; $z$ confidence level (z-score equal to 1.96 for a $95 \%$ confidence level); $e$ acceptable level of sampling error (margin of error $0.06 \% \pm 6 \%$ ); $\mathrm{N}$ population size ( $\mathrm{p}=10,415)$; and P proportion of the population ( $50 \%$; i.e., 0.5 default). From the data, a sample with a reliability of $95 \%$ and a margin of error of $6 \%$ was determined for a total of 266 households surveyed. The surveys were conducted during the months of May to August 2021.

Households from 29 neighborhoods and communities in the municipality of Puñal were randomly selected for the survey. The households were visited personally by the respondents.

\subsection{Study limitations}

The main limitation of this research was related to the pandemic The main limitation of this research was related to the pandemic situation affecting the country and the world. The restrictions limited the mobility of the researchers and their possibilities of interaction with the population studied, which caused them to take longer than expected to collect the samples.

\section{Results}

\subsection{Socioeconomic data}

A total of 266 household members were interviewed in 29 communities and neighborhoods in the municipality of Puñal. Forty percent of the households surveyed were from the municipal district of Guayabal, which has one of the largest populations in the municipality, 22\% from Puñal, which represents the most urban area of the municipality, and $4.5 \%$ from the Canabacoa neighborhood. On the other hand, the communities with interviews of less than 1\% were Colorado, El Guano, El Jobo, Los Díaz and Los Mateos. (figure 2). 


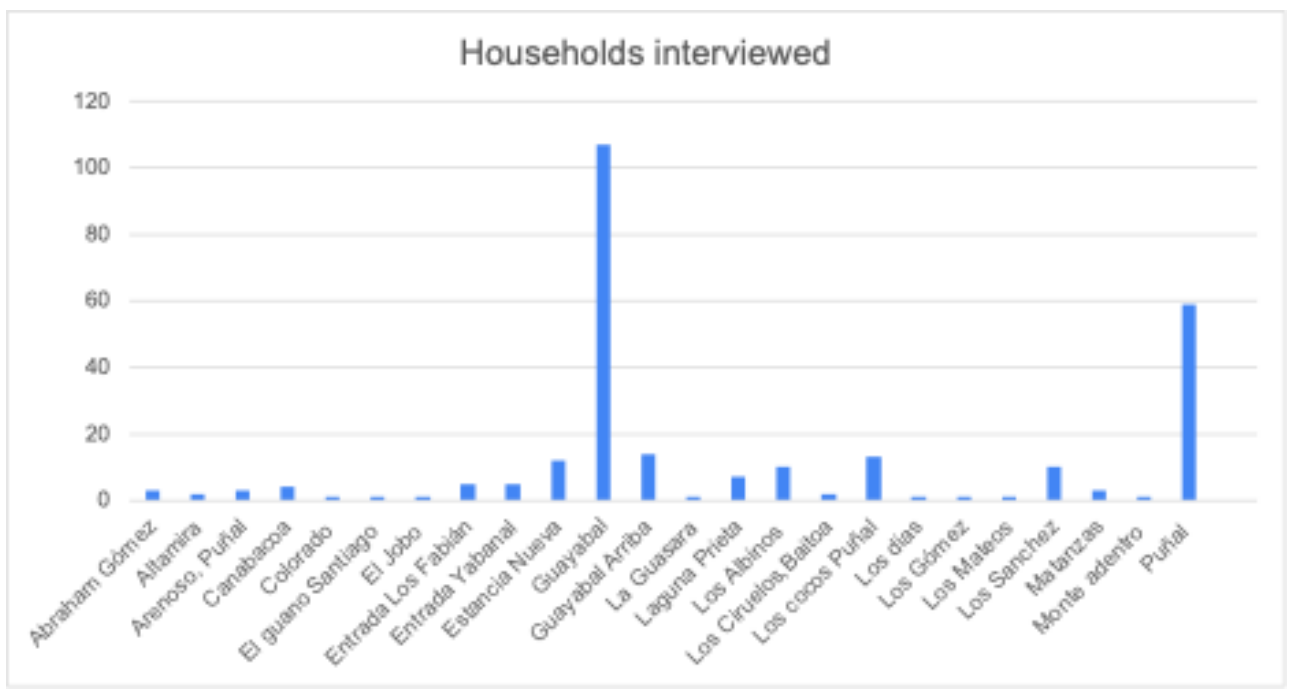

Figure 2. Distribution of residences in the neighborhoods and communities of the municipality of puñal

Concerning the educational levels (figure 3 ) of the interviewees, $40 \%$ have completed less than high school education, followed by $18 \%$ with a high school diploma, $15 \%$ with a university degree, and $12 \%$ with some college but no degree, only $3 \%$ of the respondents had no formal education, and $10 \%$ did not report their level of education.

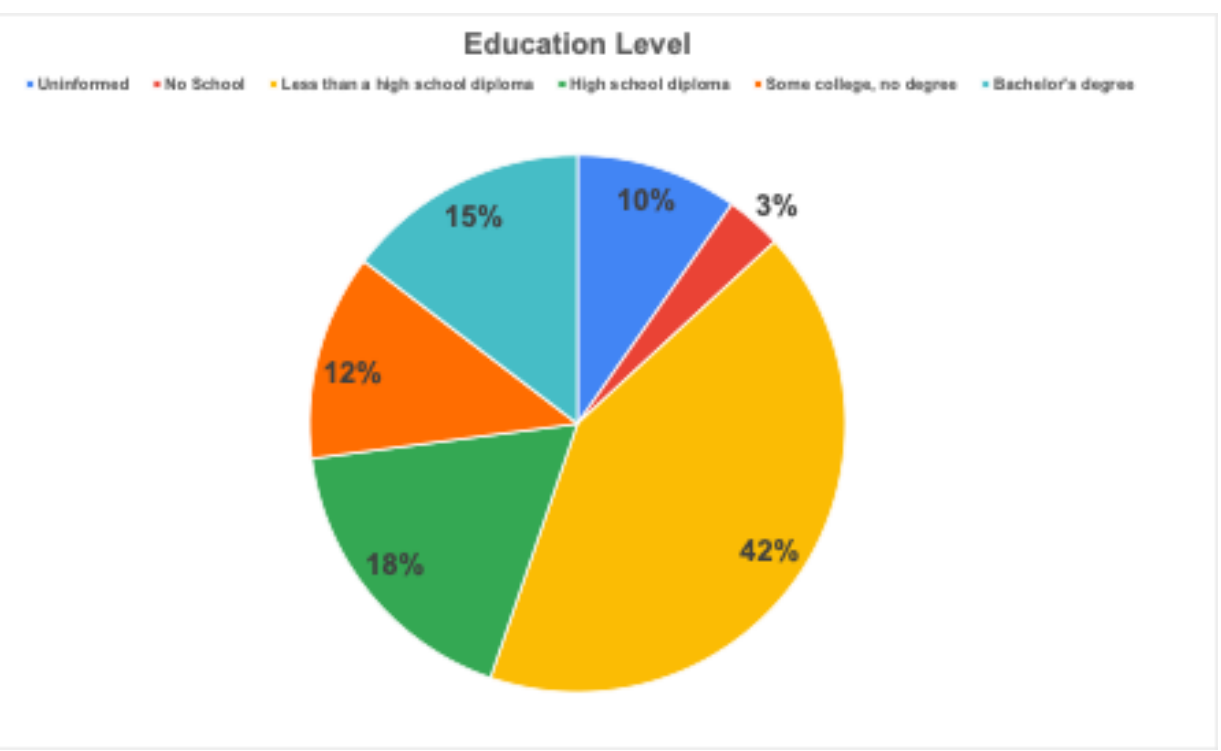

Figure 3. The highest level of education was achieved in the surveyed residences.

Regarding the number of members of the families consulted in the study figure 4), 35\% have between 3 and 4 members, 33\% have between 5 and 6 members, 19 have between 1 and 2 members, 11\% have between 7 and 8 members and only 1\% of the families have more than 9 members. 


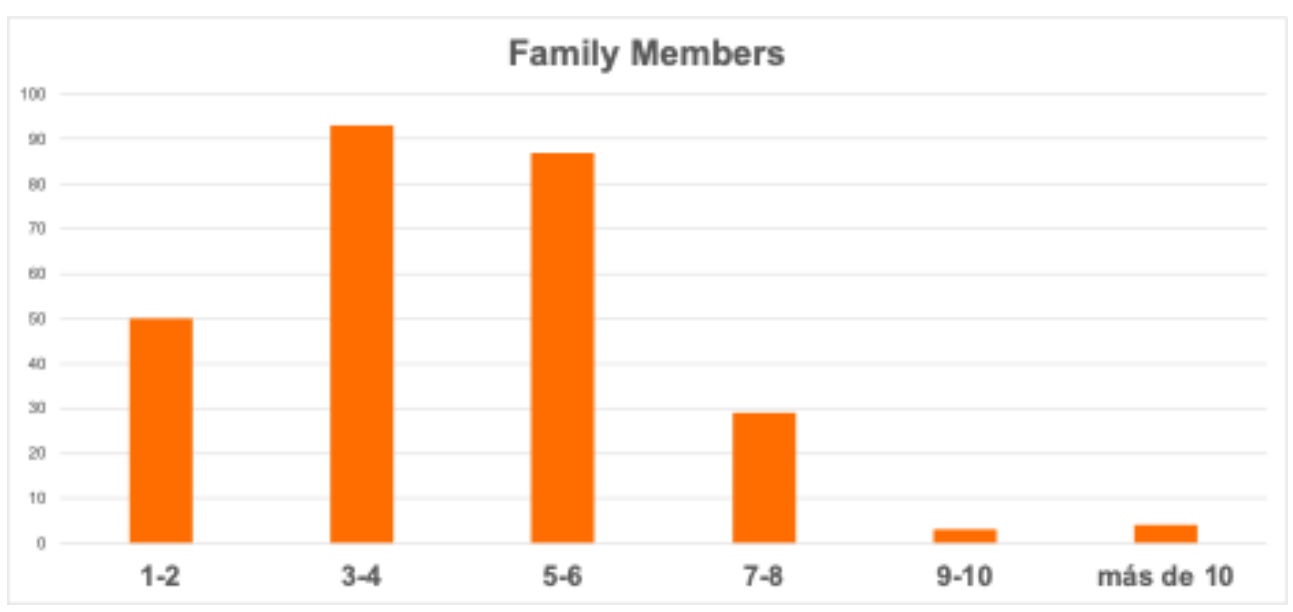

Figure 4. Family composition and number of members of the surveyed families in the municipality of Puñal.

$23 \%$ of the surveyed family has income between 100 and 200 dollars, $21 \%$ between 300 and 400 dollars, 19\% income less than 100 dollars per month, $6 \%$ between 400 and 500 dollars, in the remaining $13 \%$ this distributed among households with an income higher than 500 dollars per month (figure 5).

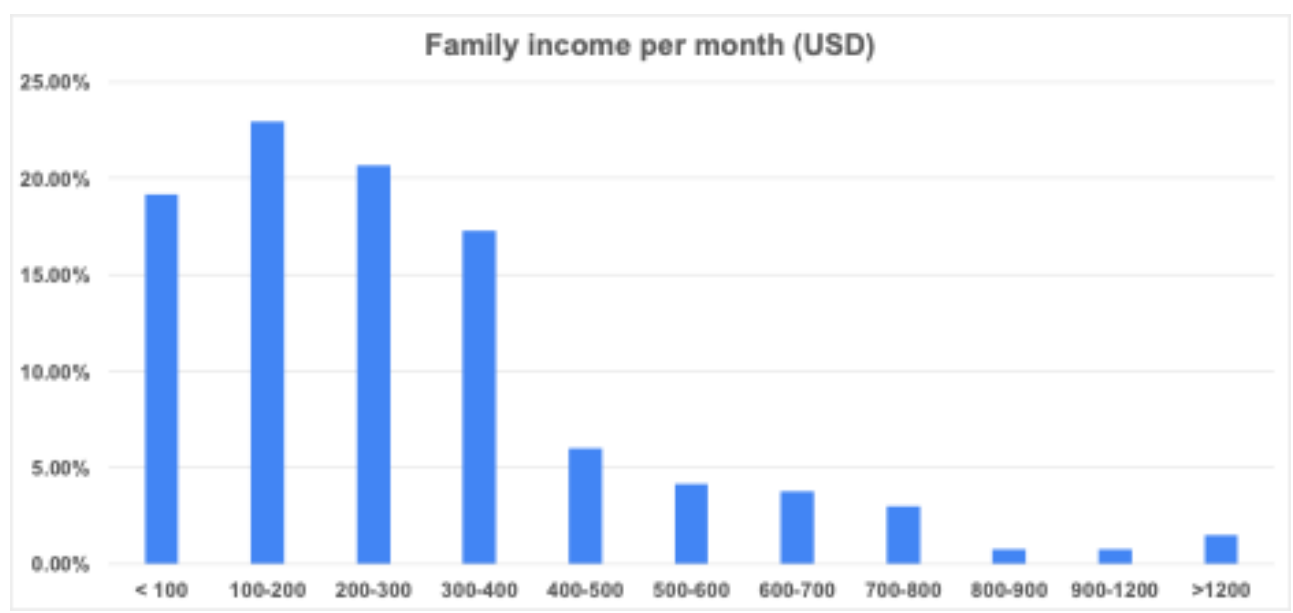

Figure 5. Monthly income of the families surveyed in the studies. Values are expressed in U.S. dollar.

\subsection{Waste generation}

The generation of solid waste was evaluated by the frequency of generation of types of waste in households, through a Likert scale in which the frequency was selected (figure 6). 


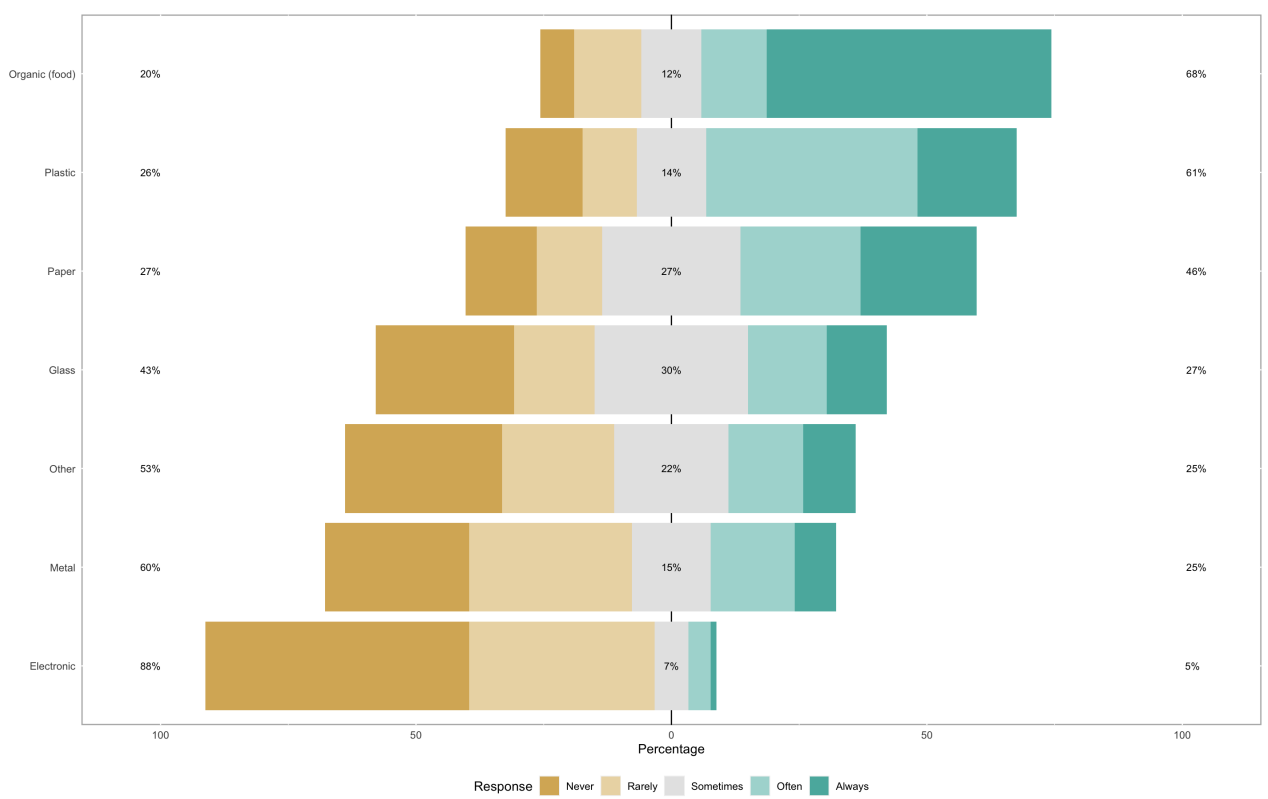

Figure 6. Likert scale for the evaluation of the generation of the different types of solid waste produced by the households that were surveyed in the municipality of Puñal.

The $68 \%$ of the consulted households always produce organic food waste that is discarded through municipal collection services. As for plastic waste, $61 \%$ frequently and always produce this type of waste, compared to glass, which is only generated by $27 \%$ of households. Sixty percent of households never or almost never produce metal waste. Similarly, $88 \%$ never or almost never dispose of electronic waste in their households. Other types of waste are only generated by $25 \%$ of the households consulted in the study.

\subsection{Storage, use, and disposal of waste}

In terms of storage, $72 \%$ of the households surveyed store their waste in garbage bags, $25 \%$ in garbage bins, $2 \%$ directly in the garbage truck, and only $1 \%$ incinerate the waste (figure 7).

\section{How is waste stored until it is thrown away?}

- Into the garbage truck - Trash bags "Garbage can = Incinerate garbage

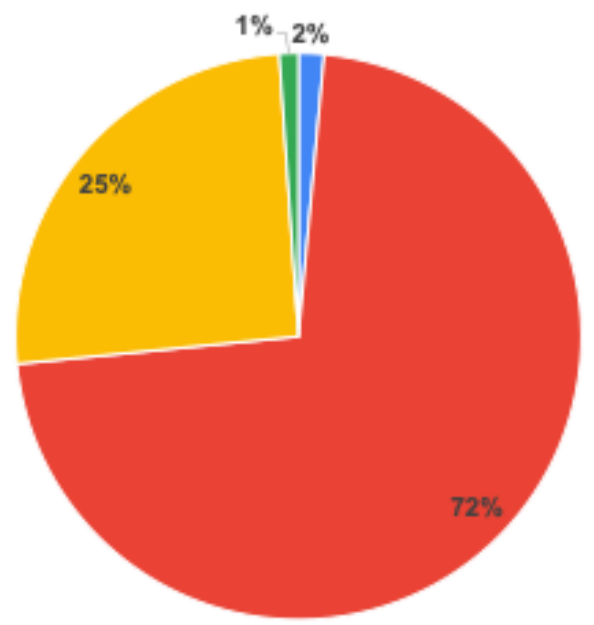

Figure 7. Methods used for waste storage in residences. 
When the use of organic waste by households was evaluated 8), 53\% stated that they do not use it at all and that they are discarded directly in the garbage truck and sent to the municipal landfill; $44 \%$ of those respondents stated that they use organic waste to feed farm animals; $3 \%$ stated that they compost it to be used as fertilizers for plants.

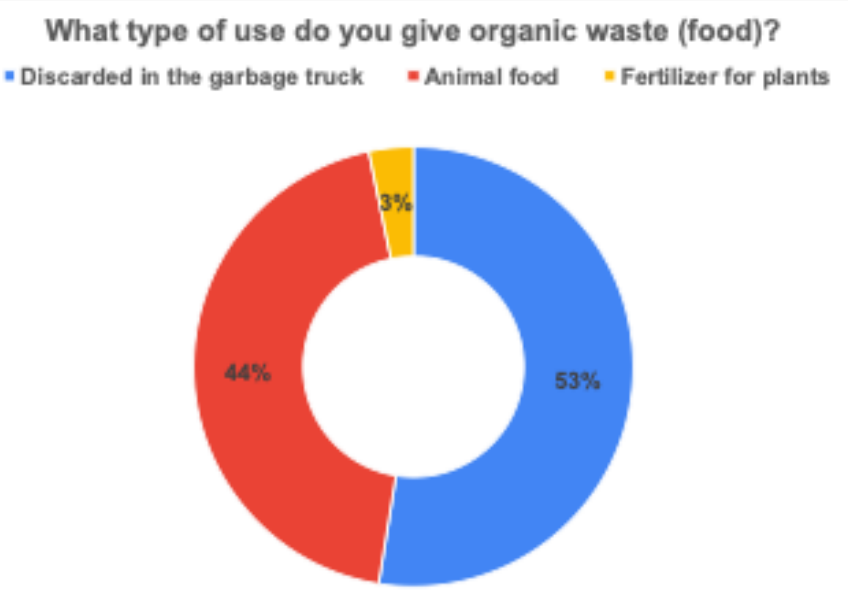

Figure 8. Use and disposal of organic waste in the surveyed residences.

Regarding collecting solid waste in residences, $97 \%$ stated that the municipality collects it through garbage trucks (Supplementary Figure 1).

\subsection{Municipal services}

Figure 9 shows the frequency with which the municipalities collect solid waste, where it is observed that in $74 \%$ of the households, waste is collected once a week, while $8 \%$ collect it daily. In $13 \%$ of the households, the collection service is performed twice week, while another $4 \%$ of the respondents stated that waste is collected every other day.

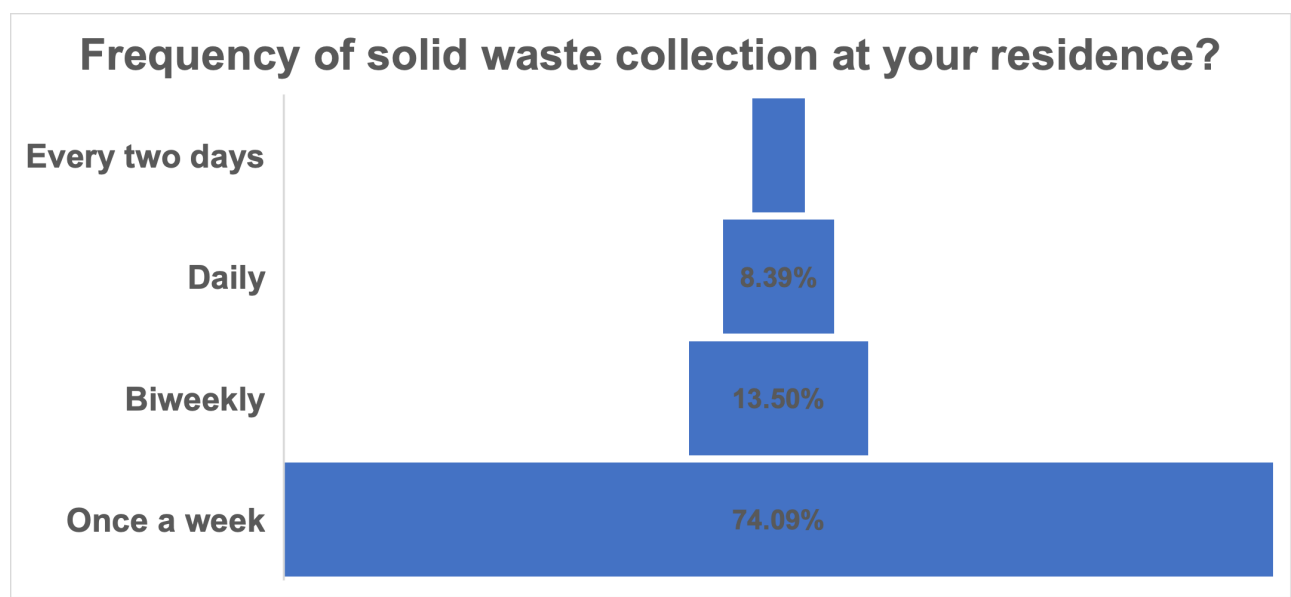

Figure 9. Frequency of solid waste collection by municipal services.

Regarding the schedule for waste collection, in $69 \%$ of the households that have this service, it is done in the morning, while in $15 \%$ it is done in the afternoon, in $3.6 \%$ of the households, solid waste is collected at night (Supplementary Figure 2).

In terms of the final disposal of waste, $52 \%$ of the households interviewed stated that they do not know where the waste is taken after collection by the municipality (Supplementary Figure 3). 


\section{Do you pay for waste collection services?}

"No $=$ Yes $=I$ dont know

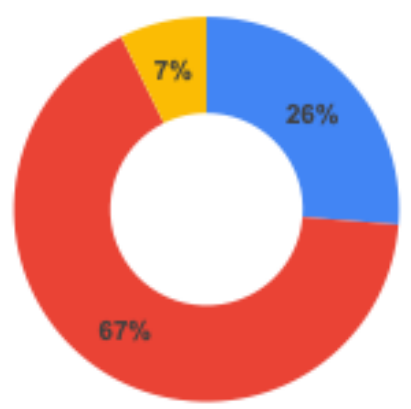

Figure 10. Distribution of the municipality's population in terms of payment for solid waste collection and disposal.

Figure 10 shows the rate of payment of the solid waste collection service to the municipalities, where it is observed that $67 \%$ of the interviewed families pay for the service, while only $27 \%$ do not pay for it, and $7 \%$ of the households declare that they do not know about the payment of the services.

\subsection{Recycling}

Regarding solid waste recycling practices, $85 \%$ of respondents stated that they do not have municipal recycling programs; only $19 \%$ of respondents practice some type of recycling at home, and only $22 \%$ perform some sorting before disposing of solid waste (figure 11).

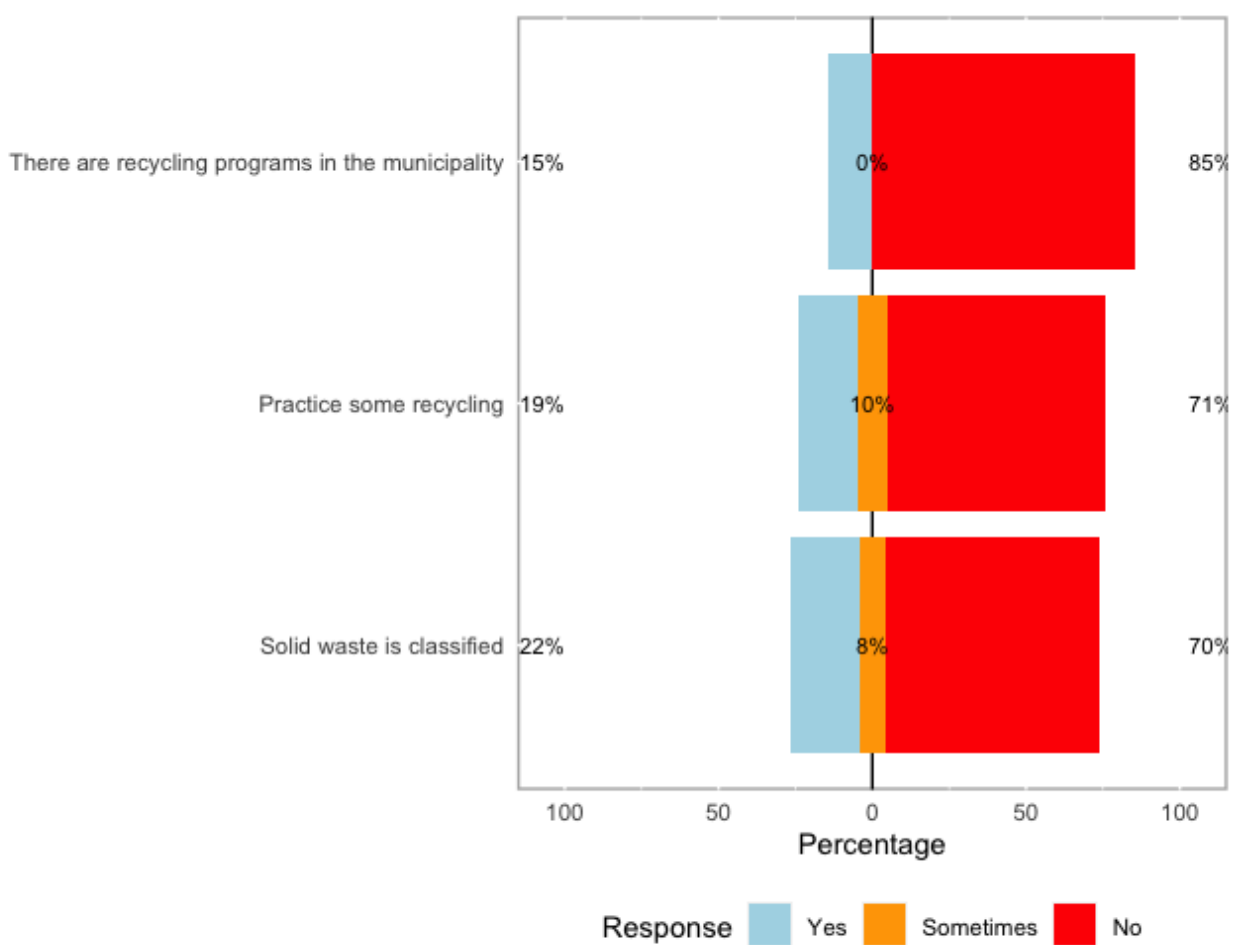

Figure 11. Representation of the recycling practiced by the inhabitants of the municipality of Puñal consulted in the study. 


\subsection{Perception of waste management}

Seventy-two percent of those interviewed indicated that they would be willing to participate in 243 recycling programs (figure 12). At the same time, $88 \%$ of the households interviewed 244 would be willing to receive some payment or bonus for their solid waste.

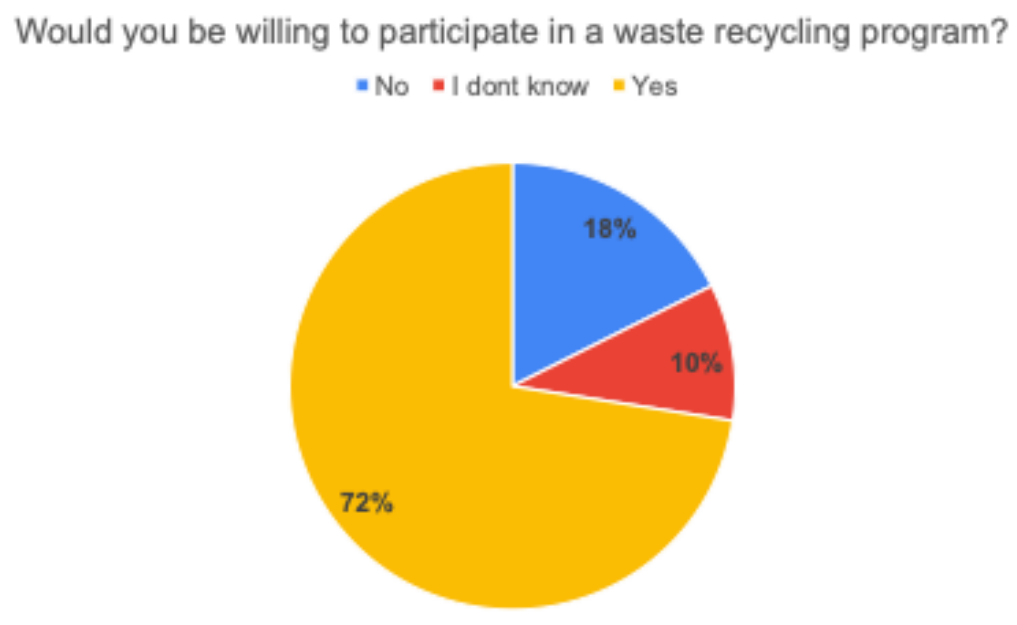

Figure 12. Motivation of the households consulted to participate in municipal solid waste recycling and revaluation programs.

Regarding the sources of garbage and landfills generated in the communities, $47 \%$ of those interviewed stated that it is due to the lack of waste collection. In contrast, $27 \%$ indicated that it is due to deficiencies in waste collection, and 10\% stated that it is due to the lack of education of the inhabitants of the municipality, and $8 \%$ to thedeficiency in the design of the waste collection routes (Supplementary Figure 4).

\section{Discussion}

The results show that there are currently few policies or programs structured by the municipalities for the classification of waste at the source and its reuse for the generation of new resources, despite the fact that laws and other agreements signed by the municipalities oblige these state institutions to develop this type of programs [3]. In the municipality of Punal, despite belonging to the "Dominican Limpia" program, no programs or projects of the municipalities were reported that encourage waste classification in the communities under study were reported [15].

The lack of a classification at source of household solid waste makes it difficult to reuse it for energy purposes due to the high levels of impurity, which would cause low efficiency in the generation of biogas. On the other hand, in many of the residences interviewed, it was found that organic waste is used to feed domestic animals or residential farms. A similar result was obtained in the survey conducted by Wolf [2], where it was evidenced that many valuable resources are not used due to the treatment received by residences or transport companies.

A worrisome situation evidenced in one of the communities analyzed is that despite having a waste collection service close to homes, many individuals stated that they use rivers and streams as the main space for waste disposal. The situation leads to the contamination of water tributaries such as the Río Yaque del Norte and its tributaries, which have become a fundamental part of the interaction with waste in the province of Santiago, which can directly affect the quality of the water used for human consumption, livestock, and agriculture [16].

Another problematic situation for waste-to-energy reuse integrating residences is the lack of access to the waste collection routes through the GPS of the collection trucks. 
This makes it difficult to calculate the amount of waste collected and where it should go for reuse.

A system of reuse of organic solids for energy purposes can be viable by integrating large producers of this type of waste such as supermarkets or other industries such as livestock, where sorting programs can be implemented quickly and efficiently at source, with which the abundance of impurities present in the waste can be minimized, allowing the production of quality biogas for industrial use.

Several companies have implemented biodigesters to produce biogas thus reuse the waste produced by their economic activity. One of these cases is that of Agropecuaria Fernández Muñoz SRL (AGROFEM), which has two biodigesters, which have enabled it to produce $70 \%$ of the energy needed for its farms from the excrement of its animals, allowing this company to reduce its dependence on fossil fuels, which ranslates into a reduction in its carbon footprint.

According to the study conducted by Cuervo and collaborators, the generation power of organic waste in the municipality of Santiago is approximately 308.8 MWh per day through Combined Cycle Gasification (GCC) [17], which indicates that the the design of a model for energy reuse of organic waste would be feasible and will allow the development of a new energy source in the province of Santiago.

\section{Conclusions}

This study made it possible to characterize the primary uses of solid waste in the municipalities of Punal, making it possible to describe the management of household waste in 29 communities of this municipality and the families, to evaluate the use of this waste for energy purposes.

Despite the deficiencies in waste management in the municipality, it has the necessary capacities to develop biogas production systems and efficient energy generation that make it possible to reuse the waste generated by its citizens. The municipality and other governmental entities should develop education and incentive programs that encourage citizens to revalue the waste at source to achieve this objective.

The reuse of organic waste can become an excellent opportunity for companies to reduce their environmental impact and generate the energy necessary for its production, which would mean savings in production costs. On the other hand, energy reuse models can become a business opportunity for entrepreneurs and a new source of employment and resources for municipalities.

Author Contributions: Conceptualization, E.F. W.P and K.P.T.; methodology, E.F. W.P.; validation, E.F. W.P and K.P.T.; formal analysis, E.F.; investigation, E.F. W.P and K.P.T.; resources, K.P.T..; data curation, E.F.; writing—original draft preparation, E.F.and W.P; writing—review and editing, E.F. W.P and K.P.T.; visualization, E.F.; supervision, K.P.T.; project administration, K.P.T.; funding acquisition, K.P.T. All authors have read and agreed to the published version of the manuscript.

Funding: This research was funded by Fondo Nacional de Innovación y Desarrollo Científico y Tecnológico (FONDOCyT) by Ministerio de Educación Superior, Ciencia y Tecnología (MESCyT) of Dominican Republic by grant number 2018-2019-2B1-217 and Universidad Abierta para Adultos (UAPA) by grant number No. 001-2020.

Data Availability Statement: Supplementary File 1: The file contains a file with the results of the surveys carried out in the municipality of Puñal and the supplementary figures.

Conflicts of Interest: The authors declare no conflict of interest.

\section{Abbreviations}

The following abbreviations are used in this manuscript:

$\begin{array}{ll}\text { MSW } & \text { Municipal Solid Waste } \\ \text { AGROFEM } & \text { Agropecuaria Fernández Muñoz SRL } \\ \text { GCC } & \text { Combined Cycle Gasification }\end{array}$




\section{References}

1. MARENA.; Maribel, C.G. Política para la Gestión Integral de Residuos Sólidos Municipales (RSM). Ministerio de Medio Ambiente y Recursos Naturales, República Dominicana 2014.

2. Wolf, J. Situación Actual de Gestión de Residuos en República Dominicana-Un Análisis en Base de Datos Levantados en el Marco del Proyecto ZACK, 1 ed.; Vol. 1, 1, Deutsche Gesellschaft für Internationale Zusammenarbeit (GIZ) GmbH, 2018.

3. del Poder Ejecutivo, C.J.d.1.R.D. Ley núm 225-20 General de Gestión Integral y Coprocesamiento de Residuos Sólidos. 109902020.

4. de Prada, M.B.; Rodríguez-Sosa, M.; Vásquez-Bautista, Y.; Guerrero, K.; Alarcón-Elbal, P. Mosquitos (Diptera, Culicidae) de importancia médica asociados a residuos sólidos urbanos en Jarabacoa, República Dominicana. Salud Jalisco 2018, 5, 20-27.

5. Pimentel Barranco, M.E. Análisis de la situación actual de la gestión de residuos sólidos municipales (RSM) de la provincia Distrito Nacional, capital de la República Dominicana. Master's thesis, Universitat Politècnica de Catalunya, 2014.

6. ONE. Encuesta Nacional de Hogares de Propósitos Múltiples 2018 [National Household Survey with Multiple Purposes-2018], 2019.

7. Barbosa, G.; Langer, M. Uso de biodigestores em propriedades rurais: uma alternativa à sustentabilidade ambiental. Unoesc E Ciência-ACSA, Joaçaba 2011, 2, 87-96.

8. Cabos Sanchez, J.D. Evaluación de las concentraciones de Nitrógeno, Fósforo y Potasio del biol y biosol obtenidos a partir de estiércol de ganado vacuno en un biodigestor de geomembrana de policloruro de vinilo. Universidad Nacional de Trujillo 2014.

9. Hrad, M.; Piringer, M.; Huber-Humer, M. Determining methane emissions from biogas plants-Operational and meteorological aspects. Bioresource technology 2015, 191, 234-243.

10. León Torres, C.A.; Nomberto Rodríguez, C.; Mendoza Avalos, G.A.; Bardales Vásquez, C.B.; Cabos Sánchez, J.; Barrena Gurbillón, M.A. Diseño e implementación de una planta piloto de producción de Biogás, Biol y Biosol. Arnaldoa 2019, 26, 1017-1032.

11. 2019.

12. Jiménez, L. De lo establecido a lo percibido: residuos sólidos en Santo Domingo y el Distrito Nacional; Vol. 1, 15, Ciudad Alternativa, 2020.

13. Oficina Nacional de Estadísticas, ONE. Tu Municipio en Cifras-Puñal. Technical Report 3, Oficina Nacional de Estadistica de la Republica Dominicana, 2020.

14. Oficina Nacional de Estadistica, O. Perfil Sociodemográfico Municipal Puñal 2011; Oficina Nacional de Estadistica de Republica Dominicana, 2011.

15. Punal, A. Dominicana Limpia : Ayuntamiento Municipal de Puñal, 2017.

16. Ferreras, R. Los desechos sólidos en la República Dominicana: su proceso y destino final. Observatorio Político Dominicano-Unidad de Gobierno Local. Informe. Santo Domingo, República Dominicana 2015.

17. Cuervo, J.; Betances, M.; Perez, E. Caracterización energética y determinación del potencial de generación eléctrica con tecnologías termoquímicas a partir de residuos degradables de Santiago de los Caballeros, República Dominicana. In press 2021, 0, 6. 
